\title{
Cryptic intermediate snail host of the liver fluke Fasciola hepatica in Africa
}

\author{
Anna Mahulu', Catharina Clewing ${ }^{1}$, Björn Stelbrink ${ }^{1,2}$, Fred D. Chibwana ${ }^{1,3}$, Immaculate Tumwebaze , \\ J. Russell Stothard ${ }^{4}$ and Christian Albrecht ${ }^{1,5^{*}}$
}

\begin{abstract}
Background: Snails such as Galba truncatula are hosts for trematode flukes causing fascioliasis, a zoonosis that is a major public health problem. Galba truncatula has recently been shown to be a cryptic species complex. African populations of Galba spp. are not yet studied using molecular assessments and is imperative to do so and reconstruct the centre of origin of Galba and to understand when and by what means it may have colonized the highlands of Africa and to what extent humans might have been involved in that process.

Methods: Samples from all known sub-ranges throughout Africa and new samples from Europe and Asia were obtained. We used a combination of two mitochondrial (cox1 and 16S) and one nuclear (ITS2) markers and phylogenetic, divergence time estimates and phylogeographical methods to determine the identity and biogeographical affinities. We also reconstructed the colonization history including the likely mode of dispersal and tested for the presence of cryptic Galba species in Africa.

Results: Galba truncatula is restricted to the Palaearctic region of the continent, namely Morocco. All sub-Saharan populations proved to be a distinct species according to the phylogenetic analyses and genetic distance. We propose to use the existing name Galba mweruensis (Connolly, 1929) for this species which is morphologically indistinguishable from the other two species hitherto known to occur in northern Africa, i.e. G. truncatula and G. schirazensis. Sub-tropical Africa has been colonized only once in either the Pliocene and possibly Miocene. Diversification within $G$. mweruensis is dated to the Plio-Pleistocene and thus human-mediated dispersal can be ruled out for the initial colonization of the isolated mountain ranges. There are potentially even more cryptic species in high altitude areas of Africa as outlined by the distinctness of the population found at the top of Mt. Elgon, Uganda.
\end{abstract}

Conclusions: From a novel genetic inspection of available African material, a hitherto neglected distinct species, $G$. mweruensis, now appears a major host of $F$. hepatica throughout sub-Saharan Africa. A closer examination of trematode parasites hosted by this species is needed in order to understand transmission patterns in highlands throughout eastern and southern Africa. We encourage future studies to inspect other high altitudes areas in Africa in light of parasites of either veterinary or medical importance.

Keywords: Fascioliasis, Medical malacology, Cryptic species, Galba truncatula, Lymnaeidae, Dispersal, Islands-in-thesky

\section{Background}

Parasitic disease caused by the liver flukes of the genus Fasciola affects hundreds of millions of people and livestock worldwide. Collectively, they cause considerable

\footnotetext{
*Correspondence: christian.albrecht@allzool.bio.uni-giessen.de

${ }^{1}$ Department of Animal Ecology and Systematics, Justus Liebig University Giessen, Giessen, Germany

Full list of author information is available at the end of the article
}

economic damage. Indeed, fascioliasis, a very debilitating snail-borne disease, is widespread across the globe; however, in the subtropical/cooler regions it is caused by Fasciola hepatica [1] whereas in the tropical/warmer regions is caused by Fasciola gigantica [2].

To complete the life-cycle, the two species of liver fluke are tied to a variety of intermediate freshwater pulmonate snail hosts of the family Lymnaeidae [3]. 
Until relatively recently, the taxonomy of snails was consolidated to a single genus Lymnaea with remarkable morphological diversity; however, with application of molecular phylogenetics a multi-generic nomenclature has become favoured with Galba and Radix now used in preference [4]. In Africa, for example, Galba truncatula (also known as Lymnaea truncatula) is involved in the transmission of F. hepatica while Radix natalensis is involved in the transmission of $F$. gigantica with any epidemiological cross-over considered to be rare [4]. As an intermediate host of $F$. hepatica, the liver fluke largely responsible for human disease, G. truncatula is characterized by its amphibious lifestyle, adaptation to cooler habitats, and its ability to withstand drought events and other harsh environmental conditions in unstable waterbodies [5]. It has been found in high altitudes in South America, where it can reach up to $4100 \mathrm{~m} \mathrm{[6]} \mathrm{and} \mathrm{it} \mathrm{is} \mathrm{thus} \mathrm{among} \mathrm{the} \mathrm{few} \mathrm{gastropods}$ reaching extreme habitats on high elevations [7].

The taxonomy of lymnaeid gastropods continues to be debated $[4,8]$, but recent molecular phylogenetic studies improved the understanding of the evolution of this major freshwater gastropod family [3, 9-11]. The species G. truncatula has been treated as belonging to Lymnaea and Fossaria in North America and is thus a prime example of taxonomic confusion in lymnaeid systematics. Galba truncatula as the type-species of the genus is conceived to be mainly a Holarctic species [12], with a wide distribution range throughout North America and Eurasia, where it reaches as far as India [13]. The scattered occurrences in South America have been interpreted as recent introductions [14]. However, the real extent of the distribution of G. truncatula on a global scale is potentially masked by the occurrence of cryptic species that are morphologically indistinguishable from G. truncatula. Among these species are Lymnaea cubensis [15] and Lymnaea schirazensis, two species that have been previously confused with G. truncatula prior to the introduction of molecular methods of characterisation. Such a confusing situation has important implications to parasite transmission and epidemiology because the cryptic species may differ in their competence for transmission of $F$. hepatica.

Given the importance of these species for veterinary and human parasitology, a number of attempts have been made to identify species based on molecular markers. As a result, a relatively rich record of sequences of several mitochondrial and nuclear molecular markers is available for comparative analyses of material studied recently [3]. On the population level, SNPs [16] and microsatellites have been published [17]. A recent study proposed an easy and inexpensive PCR-based approach to distinguish among three cryptic Galba species [15].
Despite the variety of applicable molecular diagnostic markers, there is a significant gap of knowledge about snails referred to as G. truncatula on the African continent. Here, the Galba truncatula-like snails have a disjunct distribution with four largely isolated sub-ranges: in the mountainous parts of the Maghreb states in northern Africa [18], the highlands of Ethiopia [19], some highland areas in East Africa such as Mt. Elgon [20], Usambara Mt. [21], the Kitulo Plateau [22], the highlands of Lesotho [23], and temperate coastal, i.e. cooler, regions of South Africa [24].

When compared to the other native lymnaeid species in Africa, such as Radix natalensis the main host of Fasciola gigantica, the distribution pattern of what is considered G. truncatula is particularly striking (Fig. 1) being confined to allopatry in higher altitudes [20]. The discontinuous range of G. truncatula has been hypothesized to be the result of passive dispersal by migratory birds, being more likely perhaps than an alternative of much longer historical associations with geological vicariance of uplifted African high highlands [25]. Given scattered subfossil records in the Sahara, the Near East and Namibia [21], this could represent a range of ancestral or relic habitats isolated for eons. Another possibility would be a human- or livestock-mediated introduction, given the well-recognized anthropophily of the species [26]. In fact, historical records in the eastern part of the DR Congo have been attributed to human introductions [13]. Records of the Nile Delta in Egypt recently turned out to represent populations of Lymnaea schirazensis [27] and thus raise questions as to a potential camouflaged invasion in other parts of the continent. The only populations of Galba spp. that were identified by molecular DNA to be G. truncatula inhabited Mt. Elgon [20] and the Kitulo Plateau in southern Tanzania [22]. Both studies, however, used short fragments of the highly conservative nuclear ribosomal $18 S$ gene. Whereas, this genetic marker is sufficient to delimit Galba spp. from Radix natalensis, it is not suitable for intra-generic studies. Given this situation, it remains currently unclear whether the high-altitude African populations of Galba spp. indeed represent Galba truncatula. Moreover, it is unknown how these populations are related to populations in Europe, Asia and the Americas. Due to the complete absence of molecular assessments (but see [22]) it is, to date, impossible to reconstruct the centre of origin of Galba spp. and to understand when and by what means Galba spp. may have colonized Africa and to what extent humans might have been involved in that process.

To shed new light on the phylogeography of Galba spp. populations, and its impact on snail-borne 
diseases, we examine several African populations using combination of mitochondrial and nuclear DNA markers to determine the identity and biogeographical affinities, reconstruct the colonization history including the likely mode of dispersal, and test for the presence of cryptic Galba species in Africa.

\section{Methods}

\section{Sampling}

The snail specimens studied were collected in Africa between 2010 and 2018. Field trips were conducted in the Atlas Mountains in Morocco, the highlands of Ethiopia, the Eastern Arc Mountains of Tanzania, Mt. Elgon in Uganda and the highlands of Lesotho in southern Africa (Table 1). In addition, material from outside Africa available in the collection of University of Giessen Systematics and Biodiversity (UGSB) was also used. This included material from the type-locality of G. truncatula in Thuringia, Germany. Snails were manually collected using a scoop net in stable pools, ponds, marshes, swamps and slow-running waters. Specimens were fixed in $80 \%$ ethanol prior to DNA extraction.

\section{DNA extraction, amplification and sequencing}

In most cases, DNA was extracted from two Galba specimens per locality. DNA extraction from ethanolpreserved snails was performed following the CTAB protocol of [28]. The primers used to amplify a fragment of the $\operatorname{cox} 1$ gene with a target length of 658 bp were LCO1490 and HCO2198 [29]. Amplification of the LSU rRNA fragment (16S) with a target length of 500 bp was performed with primers $16 \mathrm{Sar}$ and 16Sbr [30]. For the nuclear internal transcribed spacer ITS2, primers LT1 and ITS2-RIXO were used [9, 31].

PCR conditions were as described in [32]. Bidirectional sequencing was performed on an $\mathrm{ABI} 3730 \mathrm{XL}$ sequencer at LGC Genomics, Berlin, Germany. Galba spp. samples successfully sequenced comprised two specimens from Germany, three specimens from Greece, two specimens from Slovenia, five specimens from Russia, six specimens from Nepal, one specimen from Ethiopia, five specimens from Lesotho, nine specimens from Morocco, four specimens from Tanzania, and six specimens from Uganda (Table 1).

\section{Phylogenetic analyses}

DNA sequences were edited using MEGA v.7.0 [33]. The resulting dataset was complemented with other Galba spp. and Lymnaea spp. sequences available on GenBank (Table 1). The final dataset comprised a total of 19 specimens. The $16 S$ partition was aligned using the online program MAFFT [34], whereas Prankster [35] was used to align the ITS2 partition. The final concatenated alignment was 1494 bp long (16S: 434 bp; cox1: $655 \mathrm{bp}$; ITS2: 405 bp). Two outgroups were used for rooting the tree, Radix natalensis and Pseudosuccinea columella (Table 1).

We used jModelTest v.2.1.4 [36] to identify the bestfit substitution model for running phylogenetic analyses based on Bayesian inference (BI) as implemented in MrBayes v.3.2.6 [37]. Based on the corrected Akaike's information criterion $(\mathrm{AICc})$, the best-fit models were: $\mathrm{GTR}+\Gamma$ for $16 \mathrm{~S}, \mathrm{GTR}+\mathrm{I}+\Gamma$ for $\operatorname{cox} 1$, and $\mathrm{GTR}+\Gamma$ for ITS2. We ran two independent Markov Chain Monte Carlo (MCMC) searches (each with four chains) for 1 million generations and sampled every 50th tree and applied a 'burn-in' of $50 \%$. Convergence of the two independent runs was examined a posteriori in Tracer 1.5 [38]. Effective sample size (ESS) values of $>200$ indicated adequate sampling of posteriors distributions. In addition, a maximum likelihood (ML) analysis was conducted using RAxML-HPC2 8.2.10 [39] on the CIPRES Science Gateway [40] by applying the GTR $+\Gamma$ model to all partitions and using a stop rule for the bootstrap analysis as recommended.

\section{Estimation of divergence times}

Because of the scanty fossil record of Galba spp. and lymnaeids in general [4] and given the absence of a specific substitution rate for Lymnaeidae or freshwater pulmonate gastropods in general, we adopted a very conservative approach of dating the molecular phylogeny. We used two substitution rates for cox1, i.e. $1 \% /$ myr and $2 \% /$ myr and estimated divergence times using BEAST v.1.8.4 [41]. Analyses were run for 20 million generations, sampling every 1000th tree. Convergence of runs was analyzed using Tracer v.1.5. Because convergence was not reached and ESS values were $<200$, we applied the less complex HKY substitution model to the different partitions (i.e. 16S: $\mathrm{HKY}+\Gamma$; cox1: $\mathrm{HKY}+\mathrm{I}+\Gamma$; and ITS: $\mathrm{HKY}+\Gamma)$. The maximum clade credibility $(\mathrm{MCC})$ tree was identified using TreeAnnotator v.1.8.4 (BEAST package) by applying a 'burn-in' of $50 \%$.

\section{Phylogeographical analyses}

Phylogeographical analyses were carried out for the subset of samples from sub-Saharan Africa. The datasets consisted of 11 sequences for cox 1,11 sequences for $16 S$, and 16 sequences for ITS2 and were individually analyzed. Relationships between haplotypes were calculated using a statistical parsimony network analysis performed using the software tool TCS v.1.21 [42] with a connection limit of $95 \%$. Uncorrected genetic p-distances were calculated in MEGA v.7.0 [33] for within and among major cox 1 clades inferred from the phylogenetic analyses. 


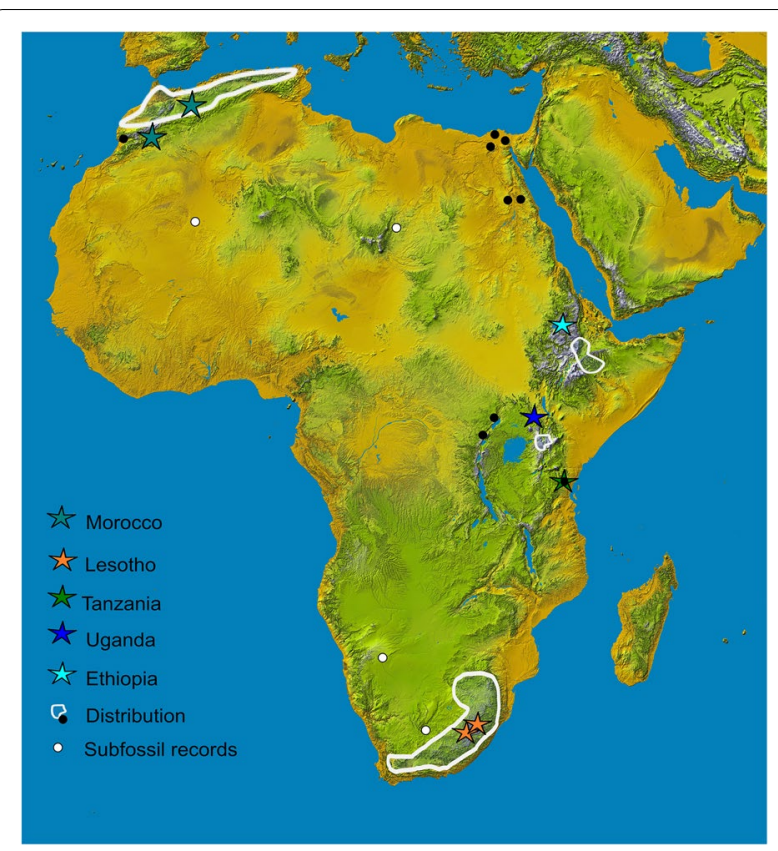

Fig. 1 Distribution map of Galba in Africa including the sampling for the present study (see Table 1 for details). Four sub-ranges hitherto known of Galba truncatula are indicated (adopted from [21] and modified from $[24,26]$. Note that occurrences on the Arab Peninsula are not shown here. Black dots denote isolated occurrences; white dots represent subfossil records. Localities of the newly obtained material are shown as coloured stars

\section{Results}

\section{Phylogenetic analyses and divergence time estimation}

The phylogenetic analyses conducted resulted in a generally highly supported phylogeny (Fig. 2) including a highly supported clade (ML bootstrap values, bs =96; MrBayes posterior probability; pp $=1.00$, BEAST posterior probability; bpp $=1.00$ ) represented by G. truncatula comprising samples from Europe (including the type-locality in Thuringia, Germany), Asia, and a single specimen from Morocco. The remaining African samples formed a highly supported monophyletic clade (bs = 98; $\mathrm{pp}=1.00$; bpp $=1.00$ ) that is referred to as G. mweruensis hereafter, which is possibly sister to G. truncatula (bs $=77, \mathrm{pp}=0.81$, bpp =1.00). Galba mweruensis (Connolly, 1929) is an available name for that clade ([43]; see Discussion). The distinction of $G$. mweruensis from $G$. truncatula is further corroborated by a more comprehensive cox1-based phylogeny (Additional file 1: Figure S1) and genetic distances (Table 2). However, both phylogenetic approaches (MrBayes and BEAST) revealed slightly different topologies. According to the MrBayes analysis, a clade of Lymnaea humilis and L. cousini was sister to the two Galba species. They together formed the sister-group to the remaining South American species ( $L$. cubensis, Lymnaea sp., and L. viatrix). The cryptic species G. schirazensis from Iran and L. diaphana are more distantly related. In contrast, the BEAST analysis suggests a closer relationship of G. schirazensis (Iran) and Lymnaea sp. (Colombia) to L. truncatula and L. mweruensis and also found differences in the more basal phylogenetic relationships.

The split between G. truncatula and G. mweruensis was estimated to have occurred between c.3.9 (95\% highest posterior density, 95\% HPD: 5.6-10.2) and c.7.8 (95\% HPD: 2.8-5.1) million years ago (Ma) depending on whether a clock rate of $2 \% /$ myr or $1 \% /$ myr was used (Additional file 2: Figure S2 and Additional file 3: Figure S3). The diversification of $G$. mweruensis started between c.1.7 (95\% HPD: 1.1-2.3) and c.3.4 (95\% HPD: 2.3-4.6) Ma.

\section{Phylogeographical analysis}

The cox 1 haplotype network consisted of six haplotypes, two of which belonged to populations from Tanzania and Lesotho each, whereas the single specimens from Ethiopia and Uganda represented unique haplotypes. These geographical haplotypes were all connected except for the populations from Mt. Elgon (Uganda) that were separated by at least 22 mutational steps from the remaining haplotypes and thus represented a distinct haplotype network based on the 95\% connection limit (Fig. 3). Similar patterns were also revealed by the $16 S$ and ITS2 datasets. Populations from Tanzania and Ethiopia seem to be more closely related in the two mitochondrial networks, whereas the ITS2 dataset suggested a closer relationship between populations from Ethiopia, Lesotho and Tanzania. The individuals from Mt. Elgon were also not connected with the remaining populations in the $16 S$ network (separated by at least 14 mutational steps) and were separated by 8 mutational steps from the other haplotypes in the ITS2 network based on the $95 \%$ connection limit.

The genetic distance within G. truncatula was higher (4.4\%) than within G. mweruensis (1.9\%). The uncorrected genetic p-distance between both groups was considerably high $(9.0 \%)$.

\section{Discussion}

\section{Identity of Galba in Africa and phylogenetic affinities}

This study found two geographically separated species of Galba in Africa. Galba truncatula is restricted based on the available evidence to the Palaearctic zone of the continent, namely Morocco. All sub-Saharan populations proved to be a distinct species according to the phylogenetic analyses and genetic distance to the sister species 
Table 1 Locality, voucher (UGSB no.), and GenBank accession information for the species studied. UGSB is the acronym of the University of Giessen Systematics and Biodiversity collection

\begin{tabular}{|c|c|c|c|c|c|c|c|c|c|}
\hline \multirow[t]{2}{*}{ Species } & \multirow[t]{2}{*}{ Locality } & \multirow[t]{2}{*}{ Latitude } & \multirow[t]{2}{*}{ Longitude } & \multirow{2}{*}{$\begin{array}{l}\text { Altitude } \\
\text { (masl) }\end{array}$} & \multirow[t]{2}{*}{ Code } & \multirow[t]{2}{*}{ UGSB no. } & \multicolumn{3}{|l|}{ GenBank ID } \\
\hline & & & & & & & $\operatorname{cox} 1$ & 165 & ITS2 \\
\hline \multirow[t]{15}{*}{ Galba mweruensis } & \multirow[t]{4}{*}{ Lesotho, Mantsonyane } & \multirow[t]{4}{*}{$29.51682^{\circ} \mathrm{S}$} & \multirow[t]{4}{*}{$28.29032^{\circ} \mathrm{E}$} & \multirow[t]{4}{*}{2212} & Gmw15772 & 23470 & MN601402 & MN602685 & MN602657 \\
\hline & & & & & Gmw15773 & 23471 & MN601403 & MN602686 & MN602658 \\
\hline & & & & & Gmw15775 & 23473 & MN601405 & MN602688 & MN602660 \\
\hline & & & & & Gmw15776 & 23474 & MN601406 & MN602689 & MN602661 \\
\hline & \multirow[t]{4}{*}{ Tanzania, Lushoto } & \multirow[t]{4}{*}{$04.44859^{\circ} \mathrm{S}$} & \multirow[t]{4}{*}{$38.17837^{\circ} \mathrm{E}$} & \multirow[t]{4}{*}{1639} & Gmw25316 & 20983 & MN601423 & MN602698 & MN602674 \\
\hline & & & & & Gmw25317 & 20984 & MN601424 & MN602699 & MN602675 \\
\hline & & & & & Gmw25318 & 20985 & MN601425 & MN602700 & MN602676 \\
\hline & & & & & Gmw25319 & 20986 & MN601426 & MN602701 & \\
\hline & $\begin{array}{l}\text { Ethiopia, Adi Aba Musa, } \\
\text { Lake Ashenge }\end{array}$ & $12.58650^{\circ} \mathrm{N}$ & $39.52100^{\circ} \mathrm{E}$ & 2409 & Gmw22773 & 17407 & MN601410 & MN602707 & MN602665 \\
\hline & $\begin{array}{l}\text { Uganda, Budadiri, Mt. Elgon, } \\
\text { Jackson's Pool }\end{array}$ & $01.14951^{\circ} \mathrm{N}$ & $34.51054^{\circ} \mathrm{E}$ & 3939 & Gmw19054 & 12151 & MN601409 & MN602706 & MN602664 \\
\hline & \multirow[t]{5}{*}{ Uganda, Mt. Elgon } & \multirow[t]{5}{*}{$01.14954^{\circ} \mathrm{N}$} & \multirow[t]{5}{*}{$34.54736^{\circ} \mathrm{E}$} & \multirow[t]{5}{*}{3792} & Gmw26767 & 22833 & & & MN602677 \\
\hline & & & & & Gmw26769 & 22835 & & & MN602678 \\
\hline & & & & & Gmw26770 & 22836 & & & MN602679 \\
\hline & & & & & Gmw26771 & 22837 & & & MN602680 \\
\hline & & & & & Gmw26772 & 22838 & & & MN602681 \\
\hline \multirow[t]{19}{*}{ Galba truncatula } & Morocco, Marrakech-Safi & $31.15573^{\circ} \mathrm{N}$ & $07.86678^{\circ} \mathrm{W}$ & 2100 & Gtr25298 & 18267 & MN601412 & MN602690 & MN602666 \\
\hline & Morocco, Timdighas & $32.68417^{\circ} \mathrm{N}$ & $05.33972^{\circ} \mathrm{W}$ & 1982 & Gtr25297 & 18265 & MN601411 & & \\
\hline & Morocco, Marlay youssef & $31.39272^{\circ} \mathrm{N}$ & $07.15383^{\circ} \mathrm{W}$ & 167 & Gtr25304 & 20971 & MN601415 & & \\
\hline & Dam & & & & Gtr25305 & 20972 & MN601416 & & \\
\hline & Germany, Thuringia, IIm & $50.89112^{\circ} \mathrm{N}$ & $11.24089^{\circ} \mathrm{E}$ & 289 & Gtr15785 & 23475 & MN601407 & MN602704 & MN602662 \\
\hline & & & & & Gtr15786 & 23476 & MN601408 & MN602705 & MN602663 \\
\hline & Greece, Rhodos Island, 7 & $36.25464^{\circ} \mathrm{N}$ & $28.11596^{\circ} \mathrm{E}$ & 232 & Gtr25308 & 20975 & MN601419 & MN602694 & MN602670 \\
\hline & springs dam lake, on mud & & & & Gtr25306 & 20973 & MN601417 & & \\
\hline & & & & & Gtr25307 & 20974 & MN601418 & MN602693 & MN602669 \\
\hline & $\begin{array}{l}\text { Russia, llovlya, river near } \\
\text { Ilovlya Town }\end{array}$ & $49.31367^{\circ} \mathrm{N}$ & $43.97659^{\circ} \mathrm{E}$ & 43 & Gtr25312 & 20979 & MN601420 & MN602695 & MN602671 \\
\hline & Russia, Moscow Region, & na & na & & Gtr25313 & 20980 & MN601421 & MN602696 & MN602672 \\
\hline & & & & & Gtr25314 & 20981 & MN601422 & MN602697 & MN602673 \\
\hline & Slovenia, Vrhnika, creek & $45.69906^{\circ} \mathrm{N}$ & $14.51176^{\circ} \mathrm{E}$ & 376 & Gtr25299 & 18543 & MN601413 & MN602691 & MN602667 \\
\hline & & & & & Gtr25301 & 18860 & MN601414 & MN602692 & MN602668 \\
\hline & Nepal, Karnali & $29.26667^{\circ} \mathrm{N}$ & $82.15933^{\circ} \mathrm{E}$ & 2300 & Gtr11234 & 23477 & MN601399 & MN602702 & MN602654 \\
\hline & & & & & Gtr12653 & 23478 & & MN602703 & MN602656 \\
\hline & Nepal, Bagmati & $29.30000^{\circ} \mathrm{N}$ & $82.36667^{\circ} \mathrm{E}$ & 2700 & Gtr11235 & 23479 & MN601400 & MN602684 & MN602655 \\
\hline & Nepal, Bheri & $29.10717^{\circ} \mathrm{N}$ & $82.58867^{\circ} \mathrm{E}$ & 2625 & Gtr11237 & 23481 & MN601401 & & \\
\hline & France, Limoges & & & & GB2 & & & HQ283236 & HQ283262 \\
\hline Lymnaea schirazensis & $\begin{array}{l}\text { Iran, Gilan Province, Taleb- } \\
\text { Abad River }\end{array}$ & & & & GB1 & & $J F 272607$ & $J F 272605$ & \\
\hline Lymnaea humilis & USA, New York & & & & GB3 & & & FN182195 & FN182191 \\
\hline Lymnaea cousini & Venezuela, Mucubají & & & & GB4 & & & HQ283237 & HQ283266 \\
\hline Lymnaea cubensis & USA, South Carolina & & & & GB5 & & & FN182204 & \\
\hline Lymnaea diaphana & Argentina, Lago Escondido & & & & GB6 & & & HQ283241 & HQ283260 \\
\hline Lymnaea sp. & Colombia, Antioquia & & & & GB7 & & & HQ283235 & HQ283263 \\
\hline Lymnaea viatrix & Argentina, Rio Negro & & & & GB8 & & & HQ283239 & HQ283265 \\
\hline Radix natalensis & Kenya, Kisumu, Lake Victoria & $00.12739^{\circ} \mathrm{S}$ & $34.74232^{\circ} \mathrm{E}$ & 1140 & Rna15771 & 23483 & MN601427 & MN602708 & MN602708 \\
\hline $\begin{array}{l}\text { Pseudosuccinea } \\
\text { columella }\end{array}$ & South Africa, Mpumalanga & $24.84539^{\circ} \mathrm{S}$ & $30.83879^{\circ} \mathrm{E}$ & 1374 & Pco15787 & 23484 & MN601428 & MN602709 & MN602683 \\
\hline
\end{tabular}


G. truncatula from Europe and Asia. Interestingly, no G. schirazensis was found at the examined localities, which further supports the hypothesis that mountain ranges of tropical Africa are inhabited by a species different from G. truncatula and its cryptic counterpart G. schirazensis has not had opportunity to disperse into these areas or is unable to do so. We therefore propose to use the existing name G. mweruensis (Connolly, 1929) for this species that was described based on shell features and size measures (for a comparison of the original type-material and our new populations see Additional file 4: Figure S4; Additional file 5: Table S1). Moreover, it is morphologically indistinguishable from the other two species hitherto known to occur in Africa, i.e. G. truncatula and G. schirazensis (Additional file 6: Figure S5). Galba mweruensis is not the oldest available name for African Galba species for which even the section name Afrogalba had been introduced by Kruglov \& Starobogatov [44]. Another taxon described earlier is Galba umlaasianus (Küster, 1862) from the Umlaas River, South Africa. Recent repeated attempts to obtain material from terra typica in the Kwa Zulu Natal Province of South Africa unfortunately failed. However, G. umlaasiana originally has been referred to as a lowland species of the temperate zones along the coastal regions of South Africa, whereas G. mweruensis has been described from mountainous terrain from Mweru town (type-locality) at the foothills of Mt. Kenya, which is somewhat in the core range of the species we found to occur widely in tropical Africa. Attempts to locate a population in the Mweru region in central Kenya in 2010 unfortunately failed. Moreover, Vinarski [45] compared both G. mweruensis and G. umlaasiana with the newly described G. robusta from Yemen and found the former two species to be morphologically different. We therefore propose to use the name G. mweruensis for mountainous Galba populations until it can be compared with topotypic material of G. umlaasianus. The latter taxon might even represent another distinct species given its different altitudinal range and may potentially co-occur with $R$. natalensis in the lower altitudes. Such a co-occurrence has not been observed for G. mweruensis in the studies that were conducted in the highlands of Lesotho (as G. truncatula in [24]), the Kitulo Plateau in Tanzania [22], and Mt. Elgon in Uganda [20]. In South Africa, however, either G. truncatula (G. umlaasianus), L. natalensis or the invasive $P$. columella have been reported to occur sympatrically [24].

Among the newly genotyped specimens of this species, the population from Mt. Elgon in Uganda is of particular interest. Mandahl-Barth [46] identified a small form of Galba at Mt. Elgon at $2770 \mathrm{~m}$ and attributed it to G. mweruensis. According to the present analyses, this population turned out to be sister to the remaining populations from Ethiopia, Lesotho and Tanzania, and the Mt. Elgon population was very distantly related to the remaining groups in the phylogeographical analyses. A more detailed analysis that investigates morphological and anatomical characters is needed in order to establish the status of the Mt. Elgon populations compared to their sub-Saharan counterparts. Hubendick [26] had material from the Kenyan slopes of Mt. Elgon and found similarities to G. truncatula but treated it as G. mweruensis. Isolated records of Galba spp. from the eastern part of the DR Congo west of Lake Albert and at Lake Kivu from considerably lower altitudes have not been confirmed during the last decades $[21,47]$.

The genetic diversity within G. mweruensis is comparable to that of other distinct Galba species such as $G$. shirazenzis [26]. Given the continuous and by far greater distributional range of G. truncatula, the higher degree of genetic differentiation in G. truncatula compared to G. mweruensis is not surprising. Nevertheless, the comparatively high genetic diversity within G. mweruensis raises the question as to how this diversity in isolated patches scattered over Africa has evolved and how these areas have been colonized. Further study in detail of several life-history traits for survival in cooler zones could be illuminating.

\section{Colonization history}

Our study indicates that subtropical Africa has been colonized only once in either the Pliocene or even Miocene if one considers the age of the most recent common ancestor of G. truncatula and G. mweruensis as indicative of colonization time. Diversification within the African species G. mweruensis is dated to the Plio-Pleistocene and thus human-mediated dispersal can be ruled out for the initial colonization of the mountain ranges. We here applied commonly used substitution rates for mitochondrial markers in invertebrates, i.e. $1 \% / \mathrm{myr}$ and $2 \% / \mathrm{myr}$ (i.e. divergence rates of $2 \% / \mathrm{myr}$ and $4 \% / \mathrm{myr}$ ). Assuming that Galba may have evolved with an extremely fast substitution rate of $4 \% / \mathrm{myr}$, the split would, of course, become younger $(c .2 \mathrm{Ma})$. However, this would not change our conclusions that the hypothesis of humanmediated dispersal can be rejected. However, the data do not currently allow drawing a final conclusion as to whether Africa has been colonized from Europe, the Near East or South America. The tree topology may favour a colonization scenario out of Europe; however, Asian and especially Near East samples of G. truncatula are scarce and G. robusta (Yemen) could not be included. Subfossil records in Africa are also not very helpful as they originate from less mountainous regions and are not very informative given the small morphospace occupied by all Galba species. However, recent and subfossil 


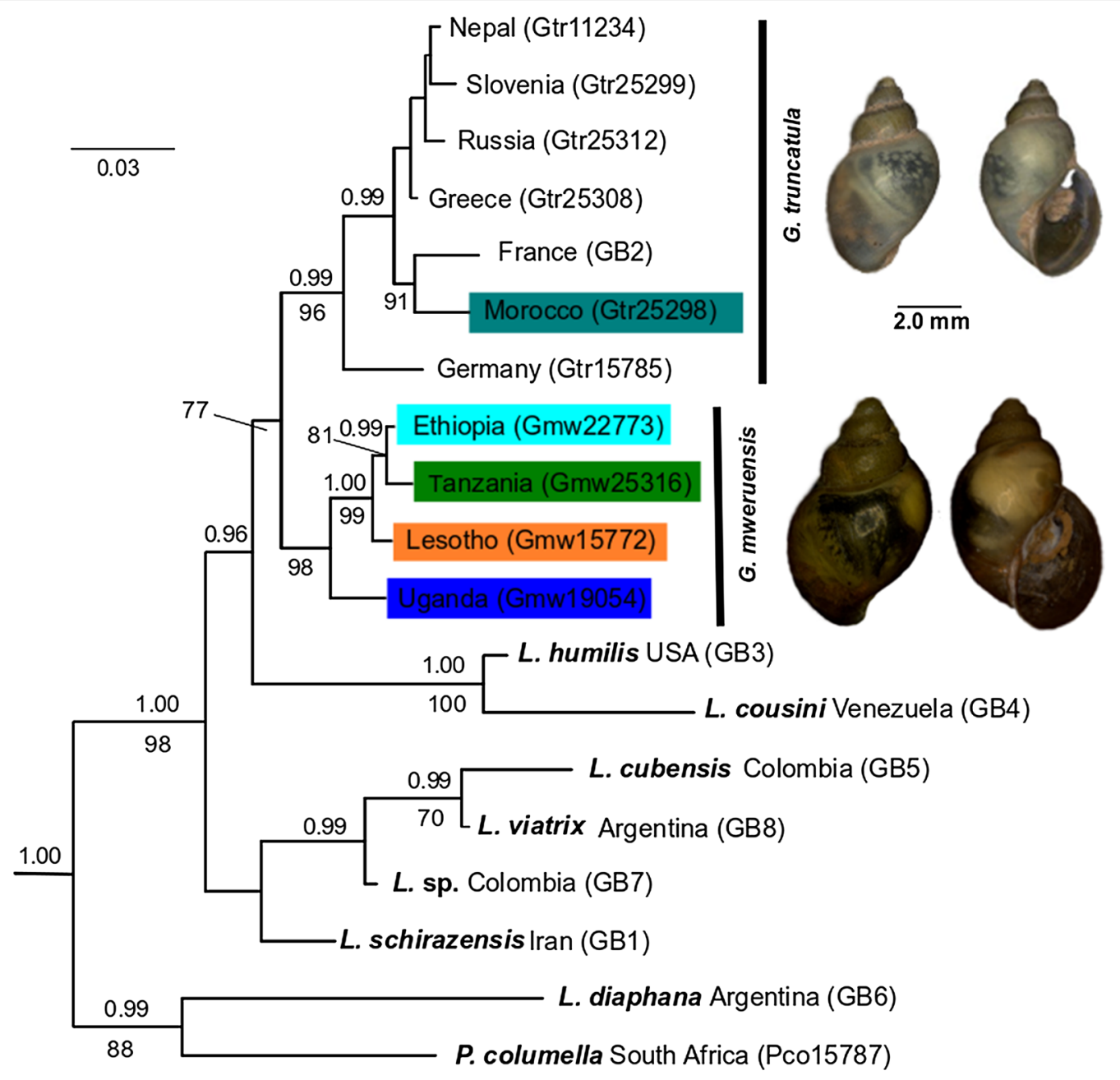

Fig. 2 Bayesian inference phylogram based on concatenated cox1, 16S and ITS2 sequences. The two outgroups have been removed a posteriori. Bayesian posterior probabilities are provided next to each node (top: MrBayes, bottom: RAxML). Sequences obtained from GenBank are labelled as GB1-GB8 (see Table 1). Nodes 1 and 2 indicate the nodes for which divergence time estimates are discussed. Colour codes used for species represent the origin of African samples and refer to those used in the map in Fig 1. Shell images are from Galba truncatula (Morocco, Gtr25298) and Galba mweruensis (Tanzania, Gmw25316). The scale-bar indicates substitutions per site according to the applied models of sequence evolution

Table 2 Genetic distances of Galba mweruensis and Galba truncatula based on the cox1 dataset

\begin{tabular}{|c|c|c|c|c|c|c|}
\hline & \multicolumn{3}{|c|}{ Uncorrected p-distance (\%) } & \multicolumn{3}{|l|}{ K2P model } \\
\hline & G. mweruensis & G. truncatula & $\begin{array}{l}\text { G. mweruensis vs } G \text {. } \\
\text { truncatula }\end{array}$ & G. mweruensis & G. truncatula & $\begin{array}{l}\text { G. mweruensis } \\
\text { vs } G \text {. } \\
\text { truncatula }\end{array}$ \\
\hline Minimum & 0.2 & 0.0 & 7.1 & $--^{\mathrm{a}}$ & $-^{\mathrm{a}}$ & $--^{a}$ \\
\hline Maximum & 4.2 & 7.8 & 9.7 & $--^{\mathrm{a}}$ & $-^{\mathrm{a}}$ & $--^{\mathrm{a}}$ \\
\hline Mean & 2.3 & 3.2 & 8.4 & 2.4 & 3.4 & 9.0 \\
\hline
\end{tabular}

Note: Uncorrected genetic p-distances and genetic distances based on the K2P model were calculated in MEGA v.7.0 [33]

a Not calculated 


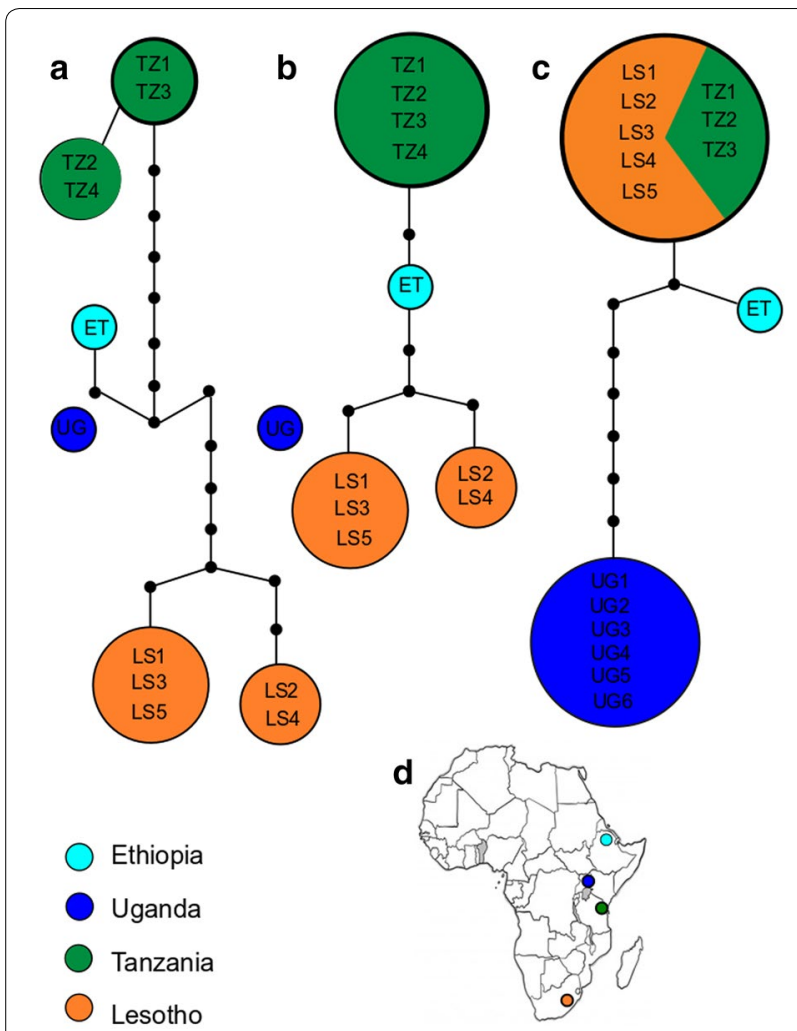

Fig. 3 TCS maximum parsimony network of Galba mweruensis based on cox1 (a), 16S (b) and ITS2 sequences (c). d Map showing the locations of the studied populations. The possible ancestral haplotypes are highlighted in bold, and the size of the circles corresponds to the number of individuals belonging to the respective haplotypes. Mutational steps representing missing haplotypes are displayed as small black circles

Saharan records $[18,21]$ may indicate a stepping-stone dispersal for the northern Africa G. truncatula populations. The generally much higher lymnaeid diversity in the northern hemisphere makes an 'out of Africa' alternative for the Galba less likely. However, given the existence of the cryptic G. schirazensis in Egypt [27], no conclusion can be drawn here. On the intra-continental scale, a closer relationship between the Northeast and East African populations in comparison to the populations of the highlands of Lesotho would be expected. However, according to our analyses, specimens from Mt. Elgon are genetically more distinct compared to the remaining subSaharan haplotypes.

Dispersal by water birds, also at high altitudes, has been commonly shown to be a major factor in range evolution for freshwater molluscs in general [48] and pulmonate snails in particular [49]. To which extent water birds might have been involved in the colonization of these isolated mountain ranges can only be speculated. If such dispersal is as frequent as demonstrated in other regions
[50, 51], G. mweruensis should be more widespread across different mountain ranges in sub-Saharan Africa.

Africa has experienced severe climatic fluctuations since the late Miocene and especially in the Plio-Pleistocene [52]. The patchy distribution pattern observed may thus reflect the emergence of climatic refugia in these mountain ranges that acted as islands in the sky [53]. Such relictary species distributions in African mountain ranges have been documented for diverse taxa such as birds [54], flightless insects [55] and frogs [56]. Although the status of G. umlaasiana has not been assessed yet, a correlation of cooler climates and the occurrence of G. mweruensis is apparent. Alternatively, the presence of the omnipresent and thus potentially competitive $R$. natalensis may considerably restrict the distribution of $G$. mweruensis to more temperate areas. Although mountain ranges are sometimes acting as refugia, they are also sensitive to climate changes [57]. Small and isolated populations might thus go through repeated bottlenecks and might experience local disappearance as found for the Galba population on Kitulo Plateau, Tanzania. A recent field survey (FC in October 2018) showed that the swampy habitats where the species earlier occurred [22] had completely dried out. A high estivating potential for Galba is, however, reported from highlands of Ethiopia [58].

\section{Parasitological implications of cryptic Galba species in Africa}

Despite its patchy continental distribution, G. mweruensis is well established, especially in the extensive sub-ranges (Fig. 1). We here confirmed its presence in regions where it has not been observed for decades such as the Usambara Mountains (Tanzania) or Mt. Elgon in Uganda. It is also the predominant snail species in the highlands of Ethiopia and Lesotho and thus should be the intermediate host for livestock fascioliasis and potentially other trematode infections in that region [19, 59]. Dinnik \& Dinnik [60] already pointed out that G. mweruensis is the intermediate host of both liver flukes, F. hepatica and F. gigantica, and thus not only represent major threats for livestock. For livestock, considerable economic losses are known from several African countries [61]. We suggest that there is a need to now ascertain the level of snail-parasite compatibility of G. mweruensis with several isolates of $F$. hepatica and F. gigantica, especially where these snails are found in cattle farmed areas.

Although estimating the prevalence of human fascioliasis is challenging [62], infection risks should be considered high wherever the intermediate host occurs [22]. Outbreaks can happen quickly, and the extent is often 
underestimated as recently outlined for the mountains in northern Tanzania [63]. Unlike with other human snailborne diseases such as schistosomiasis, there is a high prevalence in high altitude regions. A prime example is the endemic in the Andean Altiplano [14, 64]. Although high mountainous regions are still considerably remote and less densely populated in Africa, there is a growing demand for land and thus humans increasingly occupying high elevations [65]. Even touristic activities such as trekking and mountain climbing are on the rise in basically all the mountain ranges where G. mweruensis occurs so further surveillance is warranted. Therefore, more dedicated surveys on infection and prevalence rates and the study of parasites actually hosted by G. mweruensis are necessary in all the areas where this species is established [20]. Whereas G. schirazensis is not particularly involved in transmission of $F$. hepatica [27], high rates of infection have been reported for G. mweruensis (originally G. truncatula) populations from Lesotho and Ethiopia $[58,66]$.

\section{Conclusions}

This study has identified a hitherto neglected distinct species, G. mweruensis, as a host of $F$. hepatica throughout sub-Saharan Africa. It had previously been considered to be conspecific with Eurasian G. truncatula, a well-known and globally intermediate host species for several trematode parasites. Following our findings, a closer examination of the parasite communities hosted by G. mweruensis is needed in order to understand transmission patterns in highlands throughout eastern and southern Africa. Other high altitudes areas in Africa are to be surveyed for this species and veterinary and human health concerns have to be evaluated under the new precondition. It would be also interesting to study host specificity and potential climatic adaptations of both the host and the preferred temperature range of $F$. hepatica in Africa. The nature of striking non-overlap in occurrences between the omnipresent $R$. natalensis and G. mweruensis deserves more scientific attention because of its evolutionary implications and possible epidemiological cross-over as implicated host of $F$. gigantica and $F$. hepatica.

\section{Supplementary information}

Supplementary information accompanies this paper at https://doi. org/10.1186/s13071-019-3825-9.

Additional file 1: Figure S1. Bayesian inference phylogram based on cox1. The two outgroups have been removed a posteriori. Bayesian posterior probabilities are provided next to each node (top: MrBayes, bottom: RAxML). Sequences obtained from GenBank are labelled plain whereas new sequences from this study are bold. Nodes 1 and 2 indicate the nodes for which divergence time estimates are discussed.

Additional file 2: Figure S2. BEAST molecular clock tree based on an HKY model and a substitution rate of $1 \%$.
Additional file 3: Figure S3. BEAST molecular clock tree based on an HKY model and a substitution rate of $2 \%$.

Additional file 4: Figure S4. Shell measurements of Galba mweruensis populations in comparison to the type specimen as described in Connolly, 1929 (p. 175).

Additional file 5: Table S1. Shell measurements of Galba mweruensis in the highlands of Lesotho, Tanzania and Mt. Elgon in Uganda.

Additional file 6: Figure S5. Shell, soft body anatomy and reproductive organs of Galba mweruensis from Lesotho (Mantsonyane). Abbreviations: BC, bursa copulatrix; PHT, phallotheca; PRP, praeputium; VD, vas deferens.

\section{Abbreviations}

asl: above sea level; ESS: effective sample size; Gtr: Galba truncatula; Gmw: Galba mweruensis; Pco: Pseudosuccinea columella; PCR: polymerase chain reaction; Rna: Radix natalensis; UGSB: University of Giessen Systematics and Biodiversity collection.

\section{Acknowledgements}

We thank D. Engelhard (Giessen) and T. Geertz (Radolfzell) for collecting on the top of Mt. Elgon, Uganda. We further gratefully acknowledge material provided by K. Boulafasser (Casablanca), U. Bößneck (Erfurt), D. Delicado (Giessen), T. Hauffe (Giessen), A. Kossler (Berlin), and M. Vinarski (St. Petersburg). We thank P. Glöer (Hetlingen) for his help with the dissections. The comments of two anonymous reviewers helped to improve a previous version of the manuscript and are gratefully acknowledged.

\section{Authors' contributions}

AM and CA conceived the study. AM produced the sequences and performed data analyses, with the help of CC and BS. CA, CC and FC collected part of the material, and all authors were involved in data interpretation. AM produced the figures. All authors critically reviewed the manuscript. All authors read and approved the final manuscript.

\section{Funding}

AM received a PhD scholarship from the German Academic Exchange Service (DAAD), BS was supported by a Deutsche Forschungsgemeinschaft grant (DFG STE 2460/2-1) and FC was supported by a postdoctoral fellowship of the Humboldt-Foundation. CA received support from the Deutsche Forschungsgemeinschaft (DFG AL 1076/5-2, AL 1076/6-2).

\section{Availability of data and materials}

All data generated or analysed during this study are included in the article and its additional files. The newly generated sequences were submitted to the NCBI GenBank database under the accession numbers MN601399-MN601428 for cox1, MN602684-MN602709 for 16S, and MN602654-MN602683 for ITS2.

\section{Ethics approval and consent to participate}

Not applicable.

\section{Consent for publication}

Not applicable.

\section{Competing interests}

The authors declare that they have no competing interests.

\section{Author details}

${ }^{1}$ Department of Animal Ecology and Systematics, Justus Liebig University Giessen, Giessen, Germany. ${ }^{2}$ Department of Environmental Sciences, Zoological Institute, University of Basel, Basel, Switzerland. ${ }^{3}$ Department of Zoology, University of Dar es Salaam, Dar es Salaam, Tanzania. ${ }^{4}$ Department of Tropical Disease Biology, Liverpool School of Tropical Medicine, Liverpool, UK. ${ }^{5}$ Department of Biology, Mbarara University of Science and Technology, Mbarara, Uganda.

Received: 30 April 2019 Accepted: 23 November 2019 Published online: 04 December 2019 


\section{References}

1. Mas-Coma S, Funatsu IR, Bargues MD. Fasciola hepatica and lymnaeid snails occurring at very high altitude in South America. Parasitology. 2001;123:115-27.

2. Lu XT, Gu QY, Limpanont Y, Song LG, Wu ZD, Okanurak K, Lv ZY. Snailborne parasitic diseases: an update on global epidemiological distribution, transmission interruption and control methods. Infect Dis Poverty. 2018;9(7):28.

3. Correa AC, Escobar JS, Durand P, Renaud F, David P, Jarne P, et al. Bridging gaps in the molecular phylogeny of the Lymnaeidae (Gastropoda: Pulmonata), vectors of fascioliasis. BMC Evol Biol. 2010;10:381.

4. Vinarski MV, Clewing C, Albrecht C. Lymnaeidae Rafinesque, 1815. In: Lydeard C, Cummings KS, editors. Freshwater mollusks of the world: a distribution atlas. Baltimore: JHU Press; 2019. p. 158-62.

5. Dillon RT. The ecology of freshwater molluscs. Cambridge: Cambridge University Press; 2000

6. Mas-Coma S, Valero MA, Bargues MD. Fascioliasis. Digenetic trematodes. New York: Springer; 2014. p. 77-114

7. Bößneck U. Leben am Limit: Besiedlung von Süßwasser-Habitaten extremer Hochlagen Asiens, Amerikas und Afrikas durch Mollusken (Mollusca: Bivalvia \& Gastropoda). In: Hartmann M, Weipert J, editors. Biodiversität und Naturausstattung im Himalaya IV'. Erfurt: Selfpublished; 2012. p. 103-6.

8. Lydeard C, Cummings KS. Freshwater mollusks of the world: a distribution atlas. Baltimore: JHU Press; 2019.

9. Bargues MD, Vigo M, Horak P, Dvorak J, Patzner RA, Pointier JP, et al. European Lymnaeidae (Mollusca: Gastropoda), intermediate hosts of trematodiases, based on nuclear ribosomal DNA ITS-2 sequences. Infect Genet Evol. 2001;1:85-107.

10. Remigio EA, Blair D. Molecular systematics of the freshwater snail family Lymnaeidae (Pulmonata: Basommatophora) utilising mitochondrial ribosomal DNA sequences. J Molluscan Stud. 1997;63:173-85.

11. Puslednik L, Ponder WF, Dowton M, Davis AR. Examining the phylogeny of the Australasian Lymnaeidae (Heterobranchia: Pulmonata: Gastropoda) using mitochondrial, nuclear and morphological markers. Mol Phyl Evol. 2009:52:643-59.

12. Glöer P. Die Süßwassergastropoden Nord-und Mitteleuropas. Die Tierwelt Deutschlands 73. Hackenheim: ConchBooks; 2002.

13. Seddon MB, Kebapçı U, Van Damme D. Galba truncatula. The IUCN Red List of Threatened Species 2015. http://www.iucnredlist.org/detai Is/10.2305. Accessed 19 Apr 2019.

14. Bargues MD, Artigas P, Khoubbane M, Ortiz P, Naquira C, Mas-Coma S. Molecular characterisation of Galba truncatula, Lymnaea neotropica and $L$. schirazensis from Cajamarca, Peru and their potential role in transmission of human and animal fascioliasis. Parasit Vectors. 2012;5:174

15. Alda P, Lounnas M, Vázquez AA, Ayaqui R, Calvopiña M, Celi-Erazo M, et al. A new multiplex PCR assay to distinguish among three cryptic Galba species, intermediate hosts of Fasciola hepatica. Vet Parasitol. 2018;251:101-5.

16. Duffy T, Kleiman F, Pietrokovsky S, Issia L, Schijman AG, Wisnivesky-Colli C. Real-time PCR strategy for rapid discrimination among main lymnaeid species from Argentina. Acta Trop. 2009;109:1-4.

17. Trouvé S, Degen L, Meunier C, Tirard C, Hurtrez-Boussès S, Durand P, et al. Microsatellites in the hermaphroditic snail, Lymnaea truncatula, intermediate host of the liver fluke, Fasciola hepatica. Mol Ecol. 2000;9:1662-4.

18. Van Damme D. The freshwater Mollusca of northern Africa: distribution, biogeography and palaeoecology. The Hague: Dr. W. Junk Publishers; 1984.

19. Goll PH, Scott JM. Fascioliasis in the Ethiopian central highlands. Dynamics of intermediate snail host [Lymnaea truncatula] populations and their relation to infection in sheep [Fasciola hepatica, liver fluke]. Misc Rep-C Overseas Pest Res UK. 1979;47:1-12.

20. Howell A, Mugisha L, Davies J, LaCourse EJ, Claridge J, Williams DJ, et al. Bovine fasciolosis at increasing altitudes: parasitological and malacological sampling on the slopes of Mount Elgon, Uganda. Parasit Vectors. 2012;5:196.

21. Brown DS. Freshwater snails of Africa and their medical importance. London: CRC Press; 1994.

22. Walker SM, Makundi AE, Namuba FV, Kassuku AA, Keyyu J, Hoey EM, et al. The distribution of Fasciola hepatica and Fasciola gigantica within southern Tanzania_constraints associated with the intermediate host. Parasitology. 2008;135:495-503.

23. De Kock KN, Wolmarans CT, Bornmas M. Distribution and habitats of the snail Lymnaea truncatula, intermediate host of the liver fluke Fasciola hepatica, in South Africa. J S Afr Vet Ass. 2003;74:117-22.

24. De Kock KN, Wolmarans CT. The geographical distribution and habitats of three liver fluke intermediate hosts in South Africa and the health implications involved. Suid-Afrikaanse Tydskrif vir Natuurwetenskap en Tegnologie. 2008;27:1-16.

25. Mas-Coma S, Valero MA, Bargues MD. Fasciola, lymnaeids and human fascioliasis, with a global overview on disease transmission, epidemiology, evolutionary genetics, molecular epidemiology and control. Adv Parasitol. 2009;69:41-146.

26. Hubendick B. Recent Lymnaeidae: their variation, morphology, taxonomy, nomenclature, and distribution. Berlin: Almqvist \& Wiksell; 1951.

27. Bargues MD, Artigas P, Khoubbane M, Flores R, Glöer P, Rojas-García R, et al. Lymnaea schirazensis, an overlooked snail distorting fascioliasis data: genotype, phenotype, ecology, worldwide spread, susceptibility, applicability. PLOS ONE. 2011;6:24567

28. Wilke T, Davis GM, Qiu DC, Spear RC. Extreme mitochondrial sequence diversity in the intermediate schistosomiasis host Oncomelania hupensis robertsoni: another case of ancestral polymorphism? Malacologia. 2006:48:143-57.

29. Folmer O, Black M, Hoeh W, Lutz R, Vrijenhoek R. DNA primers for amplification of mitochondrial cytochrome c oxidase subunit I from diverse metazoan invertebrates. Mol Mar Biol Biotechnol. 1994;5:294-9.

30. Palumbi S. Simple fool's guide to PCR. Honolulu: Department of Zoology and Kewalo Marine Laboratory; 1991.

31. Almeyda-Artigas RJ, Bargues MD, Mas-Coma S. ITS-2 rDNA sequencing of Gnathostoma species (Nematoda) and elucidation of the species causing human gnathostomiasis in the Americas. J Parasitol. 2000;86:537-44.

32. Stelbrink B, Shirokaya AA, Föller K, Wilke T, Albrecht C. Origin and diversification of Lake Ohrid's endemic acroloxid limpets: the role of geography and ecology. BMC Evol Biol. 2016;16:273.

33. Kumar S, Stecher G, Tamura K. MEGA7: Molecular Evolutionary Genetics Analysis version 7.0 for bigger datasets. Mol Biol Evol. 2016;33:1870-4

34. Katoh K, Standley DM. MAFFT multiple sequence alignment software version 7: improvements in performance and usability. Mol. Biol. Evol. 2013;30:772-80.

35. Löytynoja A, Goldman N. web PRANK: a phylogeny-aware multiple sequence aligner with interactive alignment browser. BMC Bioinform. 2010;11:579.

36. Posada D, Crandall KA. Modeltest: testing the model of DNA substitution. Bioinformatics. 1998;14:817-8.

37. Ronquist F, Teslenko M, van der Mark P, Ayres DL, Darling A, Höhna S, et al. MrBayes 3.2: efficient Bayesian phylogenetic inference and model choice across a large model space. Syst Biol. 2012;61:539-42.

38. Drummond AJ. Rambaut A. BEAST: Bayesian evolutionary analysis by sampling trees. BMC Evol Biol; 2007. p. 214

39. Stamatakis A. RAxML version 8: a tool for phylogenetic analysis and postanalysis of large phylogenies. Bioinformatics. 2014;30:1312-3.

40. Miller MA, Pfeiffer W, Schwartz T. Creating the CIPRES Science Gateway for inference of large phylogenetic trees. 2010 Gateway Computing Environments Workshop (GCE); 2010. p. 1-8.

41. Drummond AJ, Suchard MA, Xie D, Rambaut A. Bayesian phylogenetics with BEAUti and the BEAST 1.7. Mol Biol Evol. 2012;29:1969-73.

42. Clement M, Posada D, Crandall KA. TCS: a computer program to estimate gene genealogies. Mol Ecol. 2000;9:1657-9.

43. Connolly M. Notes on African non-marine Mollusca, with descriptions of many new species. Ann Mag Nat Hist. 1929:156:78.

44. Kruglov ND, Starobogatov YI. The volume of the subgenus Galba and of the other Lymnaea (Gastropoda, Pulmonata) subgenera, similar to it. Zool Zhurnal. 1985;64:24-35.

45. Vinarski MV. Galba robusta sp. nov. from Yemen (Gastropoda: Lymnaeidae). Zoosyst Rossica. 2018;27:3-10.

46. Mandahl-Barth $\mathrm{G}$. The freshwater mollusks of Uganda and adjacent territories. Tervuren: Royal Museum of Belgian Congo; 1954.

47. Fain A. Ecological and parasitological notes on L. truncatula in the Belgian Congo. Ann Soc Belge Med Trop. 1951;31:149-52. 
48. Clewing C, Bössneck U, von Oheimb PV, Albrecht C. Molecular phylogeny and biogeography of a high mountain bivalve fauna: the Sphaeriidae of the Tibetan Plateau. Malacologia. 2013;56:231-53.

49. Von Oheimb PV, Albrecht C, Riedel F, Bössneck U, Zhang H, Wilke T. Testing the role of the Himalaya Mountains as a dispersal barrier in freshwater gastropods (Gyraulus spp.). Biol J Linn Soc. 2013;109:526-34.

50. Green AJ, Figuerola J. Recent advances in the study of long-distance dispersal of aquatic invertebrates via birds. Diver Distr. 2005;11:149-56.

51. Kappes H, Haase P. Slow, but steady: dispersal of freshwater molluscs. Aquat Sci. 2012;74:1-14.

52. Cox SC, Prys-Jones RP, Habel JC, Amakobe BA, Day JJ. Niche divergence promotes rapid diversification of East African sky island white-eyes (Aves: Zosteropidae). Mol Ecol. 2014;23:4103-18.

53. Ring U, Albrecht C, Schrenk F. The East African Rift system: tectonics, climate and biodiversity. In: Hoorn C, Perrigo A, Antonelly A, editors. Mountains, climate and biodiversity. Oxford: Wiley Blackwell; 2018. p. 391-411.

54. McCormack JE, Huang H, Knowles LL, Gillespie R, Clague D. Sky islands. Encycl Isl. 2009;4:841-3.

55. Brühl C. Flightless insects: a test case for historical relationships of African mountains. J Biogeogr. 1997;242:233-50.

56. Lawson LP. The discordance of diversification: evolution in the tropical montane frogs of the Eastern Arc Mountains of Tanzania. Mol Ecol. 2010;19:4046-60.

57. Peters MK, Hemp A, Appelhans T, Becker JN, Behler C, Classen A, et al. Climate-land-use interactions shape tropical mountain biodiversity and ecosystem functions. Nature. 2019;568:7750.

58. Goll PH, Scott JM. The interrelationship of Lymnaea truncatula and ovine fascioliasis in the Ethiopian central highlands. Br Vet J. 1978;134:551-5.

59. Prinsloo JF, Van Eeden JA. The distribution of the freshwater molluscs in Lesotho with particular reference to the intermediate host of Fasciola hepatica. Wet Byd Potchefstroomse Univ, B, Natuurwetenskappe. 1973:57:1-11.
60. Dinnik JA, Dinnik NN. A mud snail, Lymnaea mweruensis Connolly as an intermediate host of both liver flukes Fasciola hepatica L. and Fasciola gigantica Cobbold. Rep E Afr Vet Res Org. 1957;1:50-2.

61. Mehmood K, Zhang H, Sabir AJ, Abbas RZ, ljaz M, Durrani AZ, et al. A review on epidemiology, global prevalence and economical losses of fasciolosis in ruminants. Microb Pathogenesis. 2017;109:253-62.

62. Mas-Coma S, Bargues MD, Valero MA. Human fascioliasis infection sources, their diversity, incidence factors, analytical methods and prevention measures. Parasitology. 2018;145:1665-99.

63. Abdul-Hamid L, Mchaile DN, Nyindo M. Diagnosis of human fascioliasis in Arusha region, northern Tanzania by microscopy and clinical manifestations. Tanzania Vet J. 2017;32:55-61.

64. Standley CJ, Prepelitchi L, Pietrokovsky SM, Issia L, Stothard JR, WisniveskyColli C. Molecular characterization of cryptic and sympatric lymnaeid species from the Galba/Fossaria group in Mendoza Province, Northern Patagonia, Argentina. Parasit Vectors. 2013;6:304.

65. Kilungu H, Leemans R, Munishi PK, Nicholls S, Amelung B. Forty years of climate and land-cover change and its effects on tourism resources in Kilimanjaro National Park. Tour Plan Development. 2019;16:235-53.

66. Prinsloo JF, Van Eeden JA. Population dynamics of freshwater snails in Lesotho with particular reference to Lymnaea truncatula: the intermediate host of Fasciola hepatica. Wet Byd Potchefstroomse Univ, B, Natuurwetenskappe. 1976;72:1-60.

\section{Publisher's Note}

Springer Nature remains neutral with regard to jurisdictional claims in published maps and institutional affiliations.
Ready to submit your research? Choose BMC and benefit from:

- fast, convenient online submission

- thorough peer review by experienced researchers in your field

- rapid publication on acceptance

- support for research data, including large and complex data types

- gold Open Access which fosters wider collaboration and increased citations

- maximum visibility for your research: over $100 \mathrm{M}$ website views per year

At BMC, research is always in progress.

Learn more biomedcentral.com/submissions 